\title{
Back to Local Food in Urban Environment
}

\section{DE DE GRUYTER \\ OPEN}

\section{Back to Local Food in Urban Environment}

\author{
ZUZANA TURINIČOVÁ
}

Department of Ethnology and World Studies, University of SS. Cyril and Methodius in Trnava zuzu.turinicova@gmail.com

\section{ABSTRACT}

Post is focused on problems of activities aimed at local food in urban environment. The theme is studied in the view of cultural changes in nutrition in Slovakia after 1989, affecting of global phenomena, incoming of giant international companies and importing foreign food. On the other side, there is also globalizations and glolocation view as an impulse for return to local food. Post is focused on different organizations, civic associations, activities and shops, through wich people in urban environment can gain local food.

KEY WORDS: local food, urban environment, change of nutrition, globalization, community gardens, alternative farming, permaculture

\section{Introduction}

Post is focused on problems of alternative way of farming a local activism wich leads to activities focused on change to approach food in urban environment. Post is also focused on definition this phenomena, penetration and adaptation these activities in our territory and their demonstrations in local conditions.

This post is focused on the issue of local activism, reasons and results of motives both individuals and groups, that lead to activities aimed at changing the approach to food and food culture. Text is devoted to the research activities that act as a counterpoint to the global food system, bipolar consumer society and fast food establishments to domestic 
eating and local food. This text focuses on penetration and adaptation of such activities in our area. It focuses on the activities related to sustainable development aimed at obtaining food and products from local production, healthy and homemade foods that have not been produced by multinational corporations abroad.

To these problems are regarded in the view changes nutrition culture since 1989 . We can suppose that the idea to start looking for an alternative approach to gain food in urban environment is often based on trade full up with foreign restaurants, fast food restaurants, goods with poor quality from the big factories etc. Media make some pressure on people, as well. It is often said about the bad influence of fast food, chemicals in food and non quality of goods that are sold in supermarkets. Health lifestyle and bio - goods are largely presented. These aspects influenced the changes in people's way of thinking and in approach to nutrition and gardening in urban environments. Post is focused on question how preference and realization of this life style harmonizes with city life.

The phenomenon of return to domestic and local products in an urban environment can be seen in various projects aimed at promoting lifestyle associated with the return to domestic food, various lectures on permaculture in the city, community gardens, and so called "crate system", movements and associations. This type of research will also involve visits to events and traditional grocery stores.

\section{Change in Culture of Nutrition After the Year 1989}

As Rastislava Stoličná (1991) mentioned, dietary pattern at the past was mainly related to options that people had from local agricultural production. Changes gradually depended on the onset of capitalism, when production for market began to prevail and also people's purchasing power had started to rise. Therefore, percentage of goods and food purchased in stores and novel foods gradually started to surpass. Significant turnover took place after the Second World War, which was connected to the construction of business networks. Impact of collectivisation was mainly due to the change of value orientation and relation to soil and crops.

"The experience of shopping in stores during socialist was negative: consumers were meeting with lack of quantity, quality and choice of goods, with long rows and uncomfortable services" (BÚRIKOVÁ 2006:86).

In the second half of the 20th century, food culture in Slovakia has undergone several changes. These changes were affected by various factors, many of which related to the breakthrough in 1989. "Fall of communism in Central and Eastern Europe in the late eighties of the 20th century triggered an avalanche of political, economic, social and 
cultural changes ... sociologists use term transformation for a process of change in postcommunist European countries" (BITUŠÍKOVÁ 1999:6). This year, and the events related to it, led to changes in many spheres of spiritual and material culture and society as a whole. In the field of culture and the culture of eating this transformation was mainly related with the flow of new ideas and trends from abroad, opening of borders and market connected with the change the way of shopping, the amount of sorts of goods, fast food networks and influence of advertising, mass culture and marketing on consumer. On the other hand, domestic food has come after 1989 gradually into the background and stores began to sell increasing amounts of foreign food.

Dominant position of retail chains which in Slovakia dictate terms and conditions and food prices in the markets, have a destructive effect on our agri-food sector. Slovak Republic was until 1989 self-sufficient in food production and now is probably the worst in the entire European Union. Foreign import of food stands for 65 per cent, while consumer gets through retail chains up to 80 per cent of the total food in our market. One of the reasons for this unfavourable situation where hypermarkets prefer foreign food imports prior to the production of domestic suppliers is the fact that the Slovak legislation reacted late on the rapid penetration of multinational retail chains.

Also these facts we can understand as a reason why people have decided to change their approach to gain food and prioritize local food.

\section{Theoretical Framework}

This issue could be viewed from alternative ways of catering. Globalisation and globalisation processes play an important role in the transformation of eating habits in our country.

\section{Influence of Globalization}

Anthony Giddens (2010) defines globalisation as the intensification of worldwide social relations which link remote locations in such a way that local events are shaped by events that are happening many miles away. They relate mainly to economics, the arrival of foreign firms and products, as well as its culture, different views on nutrition and trends, etc. Impact of globalisation suppress ethnic diversity of the country, which can also be seen in terms of research problems on a large number of foreign restaurants, fast food establishments, selling foreign food products in stores at the expense of native ones. Here we can talk about the response to globalisation in terms of a unification on the Western image or reaction on "mcdonalisation" of society, which, according to Ritzer (1999:18) is 
the process by which the principles of quick service restaurants dominate more and more sectors of American society and the rest of the world.

This model can be applied to the whole system of this kind of nutrition and comes from the same principles. The basic principle is that it minimizes the time spent on eating. In this type of restaurant are parking lots, there are only a small selection of dishes that are quickly prepared and eaten. Also is used the principle of "finger food", the consumption of which is not necessary cutlery. "Home preparation is relatively complicated way of obtaining the food. Restaurants have begun to be built in a more efficient way, but still a lot of time had been spent there. This gradually led to the emergence of some predecessors of today's fast food establishments as were varied self-service canteens, cafes and mobile restaurants. "(STOLIČNÁ 2000:306). This is consistent with and well accommodates to today's busy man who does not have enough time to devote it to eating.

G. Ritzer (1996) in this work also builds on the idea of Max Weber that rational systems engender a series of irrationalities that ultimately limit or undermine rationality. It explains that, despite what all these establishments offer a guarantee speed, efficiency and predictability, also create many negatives and irrationality. Among those include, for example, long lines waiting for food, food is often not as cheap as the customer is mediated through ads and meals may ultimately be dangerous. They contain huge amounts of sugar, fat, salt and artificial ingredients. Another aspect is also that such nutrition has an impact on family life, because the system is disturbed by a common dining and also affects the ethnic diversity of the country in which it operates. "The decline in ethnic diversity in the nutrition is reflected precisely by the expansion of the"American" model in the fast food establishments around the world, at the expense of pubs with homemade specialties." (STOLIČNÁ 2000:311). This is on the study area, as well as elsewhere, demonstrated by the large number of Chinese, Italian, Indian and many other restaurants and fast food establishments of various kinds.

For investigating the topic I see globalisation in terms of the relationship in nutrition changes in our country. From this perspective, I look critically on globalisation and its negative consequences because of the change in food culture especially after 1989, which was connected with the change of regime, and in particular with the opening of borders and especially trade to the outside world.

Globalisation on the other hand, can directly stimulate intensification of local activism in response to its impacts. As Giddens points out, "along with stealthy and conflict-release of social relationships occurs, within this framework, as we see, amplifying of the pressure towards local autonomy and regional cultural identity". (GIDDENS 
2000:63). It should be noted that local processes and phenomena evolve along with global ones.

As Bitušíková A. (2010) reports, studying the phenomena of globalisation has led to reassessment of global versus local relationships and is increasingly used connection global and local. This coincides with the fact that many of the sites and its people who are more or less influenced by a number of global processes and phenomena, but this does not mean that they are absorbed by the global culture. These two constructs - global and local, are so interconnected that it is difficult to distinguish from each other, because one infiltrates other one. When analysing these phenomena, it is possible to distinguish both components of the process:

1. globalisation - the distribution, diffusion and universalisation of elements, patterns and relationships

2. location - selective integration, absorbing, decoding, reinterpretation and particularisation of globally dispersed phenomena, patterns and relationships (ROUDOMETOF 2003:45).

Therefore, it is necessary to take into account the interconnection of globalisation and localism, thus glocalisation as a concrete expression of local activism that originates outside of our territory and its adaptation to local conditions.

Concept of glocalization can be understood as the introduction of foreign elements in local conditions and Roland Robertson (1994) defines it as a clash of two effects - the impact of global and impact of local, which serve for balance of "globalisation" and "localisation" pressures. For the purpose of research on issues of culture nutrition this theory can be applied when looking onto ways of food activism adaptation to local conditions. To a large extent these trends arise under the influence of the West on the basis of projects and ideas that have already been implemented elsewhere.

\section{Food Studies and Social Movements}

In the countries of Western Europe and North America, the trend of local activism aimed at food began to show around in the 80 s of the 20th century. In foreign anthropological literature, this phenomenon is called "food activism" and represents efforts to achieve greater social and economic justice through nutrition practices. The task of such activism is to support various alternatives to global food and agricultural system. Such activism is manifested mainly in the form of various social movements that focus on nutrition, so called “food movements” (BITUŠÍKOVÁ 2013:40). 


\section{Back to Local Food in Urban Environment}

According to M. Nestle (2009), study of food enables to analyse social change. He argues that, since every man needs to eat, a variety of events, processes and changes can be best grasp through nutrition and related practices and experiences of everyday life. Marion Nestle highlights in particular fact, that food is changing the political to the personal various abstract concepts globalising phenomena and the free market to specific reflection of social change. According to her, "food movements" cover different groups that have in common that they are looking for healthier alternatives to the current predominant way of eating.

"Food Movement" is considered as a social movement in which people actuate in order to achieve social and cultural change" (BITUŠÍKOVÁ 2013:41), therefore conceptual approach on research of social movements and anti-globalisation movements is selected. Here I use assumption that the activities that I explore arose as a response to globalisation phenomena connected to nutrition.

In terms of social movements it is important to access to local activism from the view of its activities, reason of formation and its trending. Here it is possible to outcome from the theories of new social movements that are based on elder theories of movements from sixties and seventies of the 20th century. Social movements are defined by Giddens as collective effort to promote the common interest or to reach common goal through collective action outside of sphere established institutions (GIDDENS 2000:480). Modern theories of social movements by František Znebejánek (1997) can be devided in two streams: mainly European stream of "the new social movements," and post - material orientation and American stream wich is based on research of theory of mobilization of sources that studies organization, sources and political opportunities of movements for understanding the collective acting.

So, it is also important to look at the socio - cultural aspect of activities through which it is possible to gain local food. It can be particularly seen in the creation and operation of community gardens.

\section{Local Food}

Herbert Markus already in the 60s of the 20th century concluded that the enormous economic productivity of advanced industrial society is contrary to the free development of human needs and capabilities, such as growth of the company depends on the suppression of the freedom of individuals. The basic characteristic of advanced industrial society is in fact comfortable, conflict-free, democratic un-freedom. The standard of living is increasing, but people are paying with their freedom, with the possibility to be authentic because they are captive of false needs of mass consumerism. This is reflected in how they are subject to 


\section{Back to Local Food in Urban Environment}

advertising, indulging to what others do, hate and love what others love and hate, and so on. (p. 130).

More and more people are becoming aware of the importance of local foods that have been grown in the region in which one lives. Important is that their impact on the environment is much lesser than of the imported foods. This saves the energy for transport, packaging and quantity of resources required for its production. From an environmental point of view it supports the selection of local food and biodiversity at which local species of plants are grown and local animal species are breed. Thus, the territory retains the diversity of animal and plant species.

Many alternative directions in nutrition claim that a person who lives in the same environment for centuries adapts to the nutrition which is grows in this area and is not suitable for him to eat food from another climate zone.

In addition to supporting the environment and your health is economic aspect negligible within the issue of local food.

While the apple from the domestic supplier consumer buys in the natural state, the apple from abroad has a high consumption of packaging. To overcome the long journey, it is chemically treated. The fruit is often harvested immature, and therefore does not contain the required nutrients as than that is naturally maturated and transport to the place of purchase consumes a lot of energy and produces large amounts of greenhouse gas emissions from air transport.

Particularly sharp increase in imports is extremely negative and has dramatic impact on local food production and destroys efforts to develop local agriculture base, food production respectively.

Support of local farming is important for the economy. With the arrival of hypermarkets disappeared many small farmers that market is missing.

Every place on earth has its own sources of food, fruits and vegetables. Nature arranges for each area of the world the best and most nutritious kinds of food so that they cover the needs of all year-round vitamins and minerals and that people in those areas have received exactly the nutrients that they need for life in a given area. People should realize that they are adapted to the nutrition in the locality where they live. 


\section{Examples of Local Activism Focused on Gaining Food in Urban Environment}

\section{Permaculture (CS)}

In our country operates a civic association Permaculture (SC) in Slovakia, which is a part of an international organization Permaculture (SC), which was established in 1996. This organization is dedicated to various projects aimed at sustainable development. Since 2011 organises the festival "Permakultúra v meste". Various lectures convey information about possibilities at this festival.

Elements of the permaculture are mainly used in building community gardens operating in the selected area. This can be seen in the way of composting and the usage of space for the cultivation of crops.

"The potential of urban parks in this respect is obvious. Over time, the purely ornamental trees and shrubs can be replaced by species that are also productive, such as trees producing edible fruits and nuts, so parks can fulfil the function of food production. Allotment and urban gardens also show that cities can be productive" (WHITEFIELD 1993:35).

Also in the city center can be seen efforts to permaculture approach in the urban environment. The project started in April 2013. Part of his activity was also within the Good market, which was held at the Jacob's Square for the first time. Within it activists of the NGO Permakultúra created herb garden and the so-called "insect hotel", a great success evidenced by the fact that this event was attended by over 1000 people. Ideas like permaculture as sustainable development is also often associated with obtaining food in an urban environment, with community life and natural gardens.

Experts from NGO Permakultúra in partnership with self-governments created in the shabby and unsightly space in the so-called "herbal spiral" planted lavender, sage, lemon balm, rosemary, strawberries, chillies and many other traditional and non-traditional plants.

Permaculture is a designer approach to solve problems associated with the procurement of food in accordance to the kind of respect for nature. Permaculture design principles are based on the functioning of natural ecosystems and are inspired by natural patterns. The fundamental patterns include the development and life cycle (succession and recycling), to the different spatial patterns occurring in nature such as spirals, fractals, tree structures, and so on. Permaculture design task is to save physical labour and resources 


\section{Back to Local Food in Urban Environment}

through observation of natural laws and create the most effective system for producing food with a minimum deposit.

\section{Crate System of Food Distribution}

"Crate model" is a popular way of distributing fresh, local and seasonal organic products directly to households and is used by more and more consumers. It works in a way that farmer grows a crop that is periodically delivered by intermediaries called "debničkári" (debnička = crate, box) directly to the customer. The advantage of buying food from local suppliers is that the consumer knows exactly who, where and how vegetables and fruit grown. By buying these products we support farmers whose production we consume, and thus also support small farmers, whose work has an impact on the surrounding countryside and landscape.

This distribution includes a cartage system of fruit, vegetables and products in boxes exclusively from Slovak farmers and producers. Services associated with the distribution boxes provide for example "Debničkári", "Frou-Frou", "Debničky", Do debničky, Slovenská debnička and others. Currently, this service is becoming a popular way of obtaining and distributing fresh, seasonal, home products. Such crates are filled by local farmers, and brought directly to the consumer or to designated distribution points by already mentioned companies. On their web sites, these companies often dissuade consumers from buying chemically treated products in major shopping chains, highlight the ecological aspect of crate system and reducing the adverse environmental impact.

Recently, phenomenon "crate system" of distribution of food from local producers has extended to the private sphere. Offers for selling of domestic products in crates appear on the Internet at various sites. For example, group called "Susedský samozber" that acts on the social network facebook.com. On the site of this group people sell their surpluses from gardens and estates. Specifically, this group is focused on western Slovakia and most buyers mainly represent people from Bratislava who are not able to grow their own products. In this group you can buy vegetables and fruits from the garden, dairy, egg and meat products, as well as a variety of ready-made products such as jams and syrups. Likewise these products are put in the crates, which are also sold here. It can be stated that at present, it is a very popular way of procurement of domestic food and very popular among consumers. 


\section{Back to Local Food in Urban Environment}

\section{Slow Food Pressburg}

Subgroups know as convivia are basic units in the Slow Food structure. They are informal movements on local level and connect all people who are care in what they are eating. These are active in presentation of local traditional food and their producents (tastings, talks, factory visits, movies, creating schol gardens, markets, learning of children and young etc.).

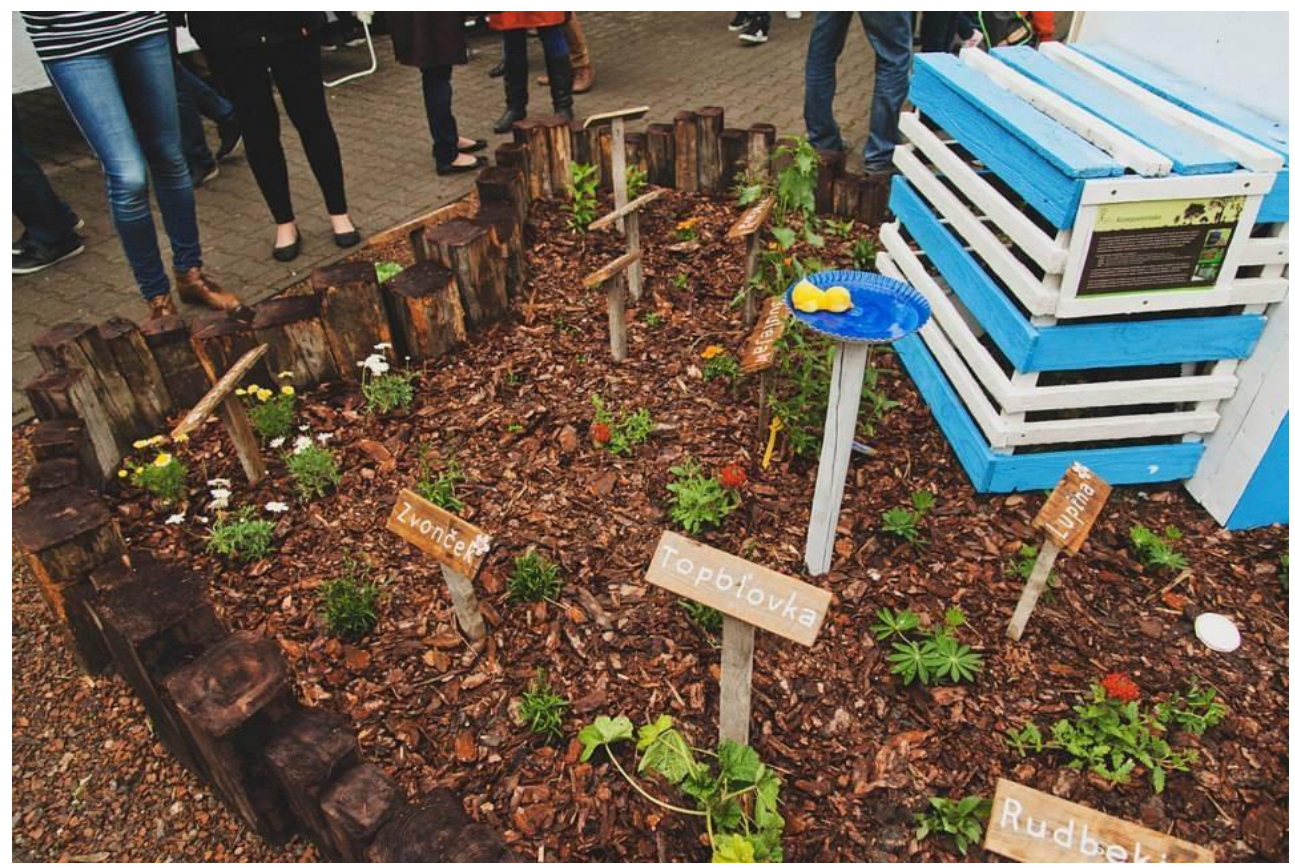

Figure 1: "Insect hotel" at the Jacob's square. Photo: author

Slow Food Pressburg was created as a subgroup of Slow Food in 2011 at the occasion of Terra Madre Day that is celebrated on december, 10th. In these day, community Slow Food all around the world oragnizes meetings to support good, pure a fair food. Basic area of this group is Western Slovakia.

The main activities of Slow Food Pressburg are promoting ideas of Slow Food, participations on projects and activities of Slow Food on national and transnational level, support craftsmen and farmers, promote their products a traditional proccesses of creation, connect craftsmen and farmers with consuments, build conscious community of consuments, support exchange of experience, support restoration and conservation regional 


\section{Back to Local Food in Urban Environment}

and national culinary heritage and co - work with other groups in Slovakia and abroad as well. ${ }^{1}$

\section{Ekoporadn̆a Živica}

Ekoporadňa "Živica" was based from the initiative of "Centrum enviromentálnej a etickej výchovy Živica“ in 2005 within the project "Ekoporadenské centrum Živica." Its goal is provide information on environment and concious consumption. They provide free guidance for individuals and for private sector.

Association "Zivica" within the project "Nevyšliapanou cestou" implements since May 2013 three activities - creates community gardens wich produce fresh fruits and vegetables, creates opportunities for meaningful spend of free time as well as building urban beehives a edition local money "Živec" wich is in force at the same time as Euro and is useable in selected stores.

The newest projet of "Živica" is building beehives in urban environment. This project isn't any new. Beehives are common part of hotel roofs, malls or basic schools. You can find bees on the balcony not only abroad but also here, in Slovakia.

Urban bees are breed in order to pollinate, save the bee population in parks, building roofs or on the balconies. Urban honey is good wich is seek for his unusual taste. ${ }^{2}$

\section{Community Gardens}

Objective of community gardens is to grow own crops and reclaim the non - using areas in urban environment. To define term community garden is not easy. The organization of garden is usually individual. There is no pattern or model how should this garden look like. Gardens can be closed or opened for publicity. Gardens are created on the public, state or private territory, mainly non - use lands where members of gardens reclaim with their work. The key point is to gain eatable crops what is the main difference between community gardens and public parks. These gardens are for growing fruits, vegetables and fruit trees. Community gardens are typical also for their structure. Garden can be based by local authority, by civic association or by group of people who are interested in gardening.

$1 \quad$ More at http://www.slowfood-pressburg.sk/)

$2 \quad$ More at http://www.zivica.sk/ 


\section{Back to Local Food in Urban Environment}

Keeping the garden can be common activity of all members or can be divaded in smaller fields that have owner.

Despite diversity, community gardens should involve four parts: territory - soil on wich the crops are grown:

- $\quad$ plants that fruits can be eat,

- members of community garden who cultivate the soil,

- $\quad$ system of organization (BUDDER 1990).

These definition can be showed on example of three community gardens in studying area. The reason of selection is different member's structure and reason of origin. Every garden was based for different purpose, by different founder, has different way of economy and organization. Into research sample belong gardens Krasnanský Zelovoc, Mobilna záhrada Sasinkova and Garden of community "Život." There is important criterium in research: all three gardens work for the same goal but by different ways. We speak about three different communities which origin and later activity outcome from different motives and have different background.

\section{Krasňanský Zelovoc}

Community garden "Krasňanský Zelovoc" was based in 2013 by young families who wanted for their children supply health crops, grown without chemical. The idea to base community garden was created in family center "Ráčik." Whose members was also the founders of garden. This garden was created on unused land behind health center rented from city district "Rača." Krasňanský Zelovoc is funded by foundation SPP and budget of capital city Bratislava. In this garden is common intergenerational co - work. Elder inhabitants of city district often come to give some advice to young members but they are no active in garden's activities.

\section{Mobila Garden Sasinkova}

Mobile garden is interesting project that is situated in Sasinkova street in Bratislava. Mobile gardens are part of project "Diery" of civic associtation "Vnôtroblok" and this one was based in 2013. The main function of mobile garden is to change unusable land to neigbourhood garden. Substance of mobile gardens is that crops are grown in portable containers and if appropriate they are able to be moved on different unuse land. 


\section{Back to Local Food in Urban Environment}

In this garden are held picnics, harvest celebrations and other events. Members can use three models of growing:

- Model city gardener (1 wooden block large as a pallet) - it is free or for voluntary fee,

- Model farmer (2 boxes) - 25 euros fee,

- $\quad$ Model landowner ( 3 boxes) - 50 euros fee.

In 2014, this garden was very popular and new member was chosen from many interested because of lack of space. Preffered was these ones who was interested in its activity earlier and these who are living close to garden. The basic idea of this garden is involve neighborhood community and to create stable social environment and by this positively influence urban life, reclaim unuse spaces and support local initiatives.

\section{Community Garden of Project "Život"}

Community garden of project "Život" was created in 2012 as the first of these three. It is a large non - using gardan wich is reclaim by volunteers for free. These people are fans of natural life style and often organized different seasonal meetings, music events and talks. Unlike the others wich are resourced from various organizations and member's fees, membership in this community is free and it is based on voluntary. This garden is also open for public. It is interesting, unlike the other garden that are connecting mainly people who are from Bratislava or they are living here and is giving them contact with nature in urban environment, members of this garden often live in different district of Slovakia. Important motivation for their membership is also the possibility to work in garden wich they have at home but here they miss it. This garden has any special rules. They organize communal events, brigades etc. Soil for growing is choosed by everyone. Organization is based on founder of this garden - Maník, founder of project "Život," who for example created event "Zóna bez penňazi" or every year organizes natural fair on Drienok. Once a week, kindergarten who is close to the garden is coming to children could be in touch with nature.

Structure and reason of membership are various. From the point of view of studied sample, we can say that the most members are families with children and young people. Respondents have said that their main reason to be members is spending time in community with possibility to gain health crops. From the actual research is clear that apecto of creation the community and alternative way of spending time in urban environment is more important than growing the crops. 


\section{Back to Local Food in Urban Environment}

As it was said, community gardens are very popular today and there are nowdays created new ones. They are based by different civic associations and city districts. For example, in district Nové mesto was created community garden at basic school. In this garden, children are learned how to grow crops and homeless people help them with harder manual labor. The other community garden in Bratislava are for example: community garden wich was created on the terrace under the Slovak radio, "Záhrada pod pyramídou," community vineyard in district Nove mesto, several "inside - block" gardens which was created on unused territories between prefabs in districts Petržalka and Dúbravka, community garden of water company of Slovakia and the others.

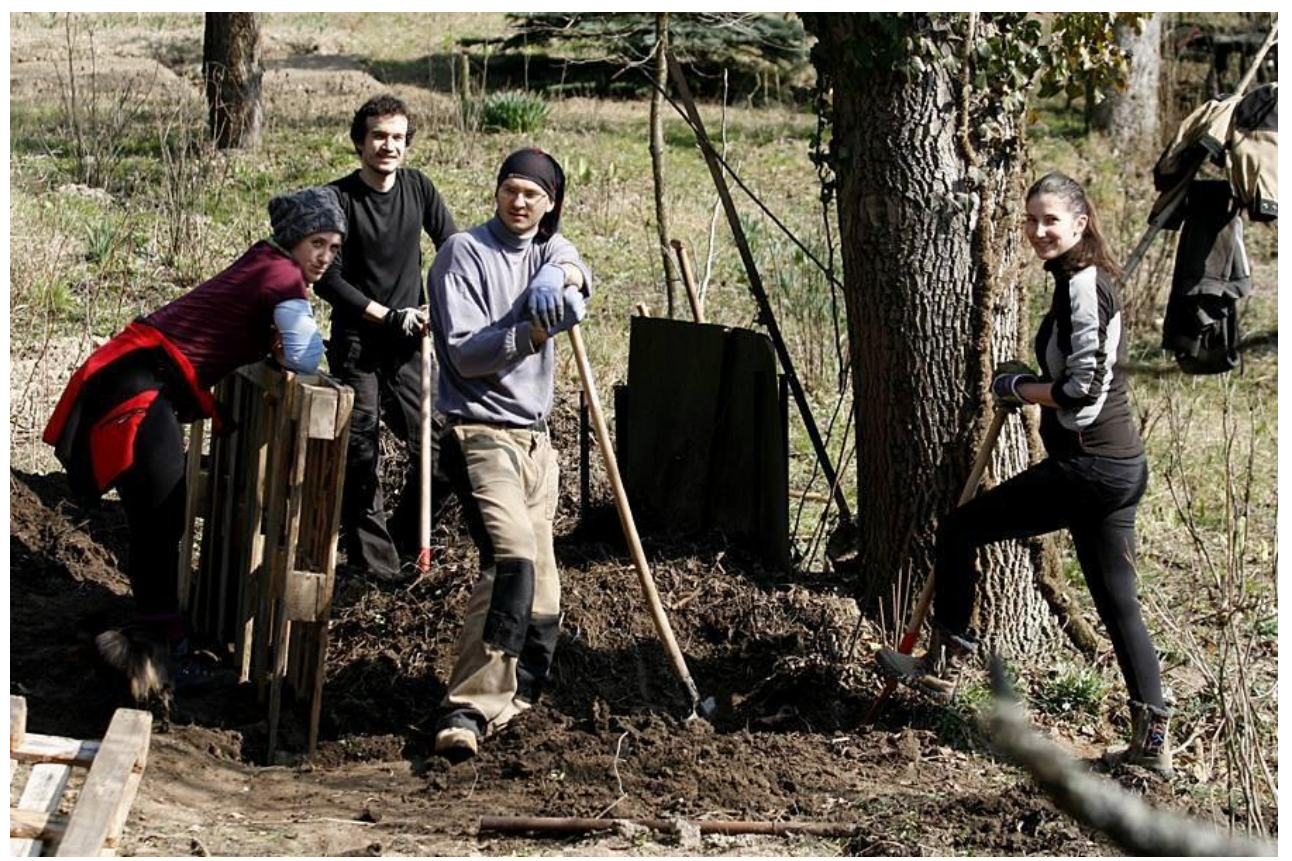

Figure 2: Building a community garden composting in project „Život”. Photo: author.

\section{Events and Shops}

Today in Bratislava are organised several events that are dedicated to the research topic. Increasingly popular become variety of farmers' markets, where mainly local growers sell their products. Several events are organised where domestic and bio-products are presented, such as "Gurmanfest" or "Dobrý trh". 


\section{Back to Local Food in Urban Environment}

"Dobrý trh", was established in 2011 on the initiative of "NGO Punkt". It revitalises public urban space, open courtyards and streets for people, creating space for meetings and experiences. It supports small producers and quality home products. It is designed just for the local community that actively participates at the market, as well as for all residents and visitors of the city. "Dobrý Trh na Jakubáku" (Jacob's Square in the city of Bratislava Staré Mesto) focuses exclusively on quality food, healthy lifestyle and environment. The "good, clean and fair food" rule must be followed by gastro establishments that cook from raw materials originating in the maximum extent possible, directly from the farmers and food producers.

Also, the number of stores that offer traditional products from domestic raw materials is increasing, like "Starý otec" or "Múzeum v obchode", which also sell products manufactured according to traditional "Pressburg" recipes.

Recently even online stores that offer home products started to rise. Here we can include various stalls and groups that bring together growers and producers and promote advertising of their goods.

\section{Conclusion}

Globalization and globalization processes play important role in the process of transformation in eating habits in our territory. They are related mainly with economic side, incoming of foreign companies and products as well as with culture, opinions on nutrition, trends in nutrition etc. In this sphere we can speak about "rolling" the traditional way of nutrition. Big influence is from globalization, trends and from mass - produced food which has been since 1989 promoted also in our territory. That type of nutrition is promoted mainly by network of supermarkets and by potable way of life. Return to local and home products has often source in surfeit of market with foreign restaurants, fast food restauratns, non - quality foreign products from mass production etc. Important question is, what is the rate of return to local products. These trends are often influenced by trends from Western world where it has been already realised. Here we can speak again about influence of globalization or about glocalization as about straight response to suggestions in local conditions.

Today, community gardens are preferred way of spending free time. It still grows up and is very popular in urban environment. In the study area, the new gardens are based and have different member base, reasons of origin and organization. Community gardens are interesting example of alternative economy in urban environment. People in cities often don't have any other opportunity to grow their own crops and don't want to buy crops from abroad, so they choose this way how to gain health products. Important aspect, on wich we 


\section{Back to Local Food in Urban Environment}

must focus is, that not only way of economy but also creation a social bonds among members is significant. Community gardens are created especially by people from same or close territory of garden and serve from creation of new as well as for retain already created relationships. We can say that in study area where life and neighborhood are still more anonymous, fellowship and relations are lost, community gardens contribute to creation of community in urban environment. For members of these gardens it is also a motive for escape from everyday stereotype life, sedentary job and from anonymity of city.

Activities of different civic organizations and movements as are "Permakultura" (CS), Slow food Pressburd and "Ekoporadna Zivica" are important from the point of view raising awareness. These organizations help to producers, associate them, learn through different talks, workshops and promote their products. Also, important is an interconnection of producers with customers and mediation of options for selling their products.

The system of selling wich is know as a "crate system" of crops from local producers, different events, farmer's markets and shops are the way how to gain crops in business sector. People more think about what they eat and step by step start to preffer home products instead products imported from foreign countries. They recognize the higher quality of these products and less impact on environment wich is based on distance the products are imported from. Greatly is also important the idea of supporting home producers. These idea is very popular and in the study area, there are still created new initiatives and shops focused on local products and crops.

Issues of local activism that is related to alternative way of economy is a new phenomenon that monitors actual trends and this is why we can study it in actual context. This post presented sight to theoretical approach to the theme and overview of activities through these we can gain local crops in urban environment. Showing the concrete examples of these activities it describes options of aleternative approaches to local products.

\section{Bibliography}

BITUŠíKOVÁ, A. (2013):Cesty k udržatel'nému životnému štýlu. In. Kultúrna a sociálna diverzita na Slovensku. Bratislava: Ústav etnológie SAV, pp.36-51

BITUŠíKOVÁ, A. (1999): Kontinuita a zmena v urbánnom kontexte (Sociálnoantropologické reflexie výskumu mesta a spoločnosti). In. Banská Bystrica, premeny mesta a spoločnosti. Banská Bystrica: Inštitút sociálnych a kultúrnych štúdií, Fakulta humanitných vied, Univerzita Mateja Bela v Banskej Bystrici, pp.6-59. 
BÚRIKOVÁ, Z.(2006): Spotreba a výskum reálne existujúceho socializmu. In. Etnologické rozpravy. Bratislava: Ústav etnológie SAV, pp.81-91.

GIDDENS, A. (2000): Sociologie. Praha: Argo.

GIDDENS, A. (2010): Důsledky modernity. Praha: Slon.

MARCUSE, H. (1991): Jednorozměrný člověk. Studie o ideologii rozvinuté industiální společnosti. Praha: Naše vojsko

NESTLÉ, M. (2007): Food politics. University of California Press.

RITZER, G. (1996): Mcdonalizace společnosti. Praha: Pine Forge Press and Sage publications.

ROBERTSON, R. (1994): Globalization or glocalization. In. Journal of International Communication, pp.33-52

ROUDOMETOF, V. (2010): Glocalization, Space and Modernity. In. The European Legacy, pp.37-60

STOLIČNÁ, R. (1999): Jedlá a nápoje našich predkov. Bratislava: Veda.

STOLIČNÁ, R. (2000): Fast food: globálny fenomén súčasného stravovania a spôsobu života. In. Slovenský národopis, No.3, pp. 305-313

ZNEBEJÁNEK, F. (1997): Sociální hnutí. Praha: SLON.

WGITEFIELD, P. (1996): Permakultura v kostce. Praha: Synergie. 